\title{
The Antecedents of Electronic Loyalty in Indonesian C2C E-Commerce
}

\author{
Hendra. \\ Business and Economics Faculty, \\ International Marketing Management \\ Universitas Sumatera Utara, \\ Wilmar Bisnis Indonesia Polytechnic \\ Medan city, Indonesia \\ hendrazhicheng@gmail.com \\ Paham Ginting \\ Business and Economics Faculty \\ Universitas Sumatera Utara \\ Medan city, Indonesia \\ pahamginting3@gmail.com
}

\author{
Endang Sulistya Rini \\ Business and Economics Faculty \\ Universitas Sumatera Utara \\ Medan city, Indonesia \\ endangsulistyarini@yahoo.co.id
}

\author{
Beby Karina F. Sembiring \\ Business and Economics Faculty \\ Universitas Sumatera Utara \\ Medan city, Indonesia \\ Biring.beby@gmail.com
}

\begin{abstract}
As the number of Indonesian internet users increased significantly in January 2017 compared to January 2016, with additional internet users $51 \%$, was the highest in Southeast Asia and mobile payment users and penetration in Indonesia is expected to more than double by 2017, it has been great opportunity for E-Commerce to grow in this current digital economy as agreed at World Economic Forum 2016 in Switzerland. Currently, there has been quite a number of new ecommerce coming up and it has made the customers having more alternative in choosing products and services to purchase. Tokopedia is one of E-Commerce that run in C2C, which provides free online marketplace for sellers to open their own estores and earns revenues from user upgrades, premium accounts and TopAds advertising services. Reference revealed that Tokopedia's bouncing rate is more than $30 \%$ and in common, Indonesia's E-Commerce switching behavior is more than $50 \%$. This research is meant to find out the antecedents of electronic Loyalty for C2C E-Commerce. The samples are 169 customers from several cities in Indonesia who have ever made online shopping at Tokopedia.com. The sample collection technique would be done by using nonprobability sampling. The data analysis technique would be done by using multiple linear regression using SPSS statistical software. Based on the result of model feasibility test, it displays that the independent variables have very high significance influence to the electronic loyalty. The partial result of $t$ test reveals that though E-Recovery Service quality does not influence electronic loyalty, but electronic service quality has positive and highly significant influence to the electronic loyalty. Ultimately, in order to create electronic loyalty for Indonesia C2C E-Commerce, it has to focus and boost its electronic service loyalty through its touch point, fulfillment, privacy, efficiency and system availability
\end{abstract}

Keywords - Electronic Loyalty; Online Shopping

\section{INTRODUCTION}

Reference [1] mentioned that the current economy can be called digital economy. Indonesia as one of the emerging economy has also developing its digital sector as the internet users has been growing rapidly and in 2017 has become the highest users in Southeast asia. It has created a flourishing market opportunity for E-Commerce market players to grow. One of the top e-commerce market is Tokopedia which runs in $\mathrm{C} 2 \mathrm{C}$ platform. But reference [2] revealed that its bouncing rate is more than $30 \%$, which means in 100 customers who browse the e-commerce, 30 customers leave the page at once and Indonesian E-Commerce switching behavior is more than $50 \%$ which means five out of ten customers switch e-commerce once they use it. Thus, electronic loyalty is at peril, which could hinder the e-commerce growth. Electronic Service Quality (E-S-Qual) and Electronic Recovery Service Quality (E-RecS-Qual) have high effects on electronic loyalty [3]. ES-Qual and E-RecS-Qual has positive strong relationship toward Loyalty in online shops [4]. The dimension [4] are similar to [5] for E-S-Qual are efficiency, system availability, fulfillment, and privacy. Where E-RecS-Qual dimension are Responsiveness, Compensation and Contact. This study offer one additional dimension besides the four dimension above to E-S-Qual, which is Touch Point, the emotions and feelings aroused from customers interaction with e-commerce website, and it is aldo called moment of truth. With this new dimension and the absence of other c2c e-commerce study, it is expected to show originality of this study.

\section{ELECTRONIC LOYALTY}

To obtain and maintain customer loyalty is the supreme aspiration of many modern online retailers [4] because loyal customers are much willing to purchase and spend more, easy 
to access, and even could provide WOM (word-of-mouth marketing) for the e-commerce if they are enthusiasts. [6]

The previous study suggests that online e-commerce enjoy electronic loyalty compared to brick and click e-commerce for half of its sales is from loyal consumer. Reference [7] suggests only a very small number of e-commerce visitors return to make purchases however this small number of loyal buyers are very profitable [8], so that they are worth to be taken best care of [6]. A small increase of percentage of loyal purchasers in ecommerce contributes superior profit in online business [9].

There are two types of loyalty, attitudinal and behavioral loyalty [10]. Attitudinal loyalty shows long-term psychological customer commitment to an e-commerce. It can be seen from the psychological involvement, favoritism, and a sense of goodwill on certain e-commerce. Whereas Behavioral loyalty can be referred to as the purchase of product or service from customers of e-commerce.

Reference [5] measures loyalty from the behavioral items, like positive word of mouth, recommend, encourage the usage of e-commerce, first choice for future transaction and do more business in the coming months.However, reference [11] measured loyalty by two dimensions, that are word-of-mouth communication (WOM) and repurchase intentions. This study will try to combine the usage of both attitudinal and behavioral online loyalty that consists of three dimensions, which are Purchase Intention, Continued Interaction and Buzz Marketing. Purchase Intention is the willingness to keep using, visit and make purchase at the same e-commerce site. Continued Interaction is the consistency of using the same ecommerce site for a period, two years for instance. Buzz marketing is volunteering will to advocate and share information to family, peers or acquaintances or others about product/ services in an e-commerce.

Electronic Service Quality has been proven to promote electronic loyalty [5] and online customers do not have the interest to make extensive search and with e-commerce which they ever experienced, they have no problem in making transaction with the premium price [12]. Thus, priority of any e-commerce should be winning customer loyalty.

This study tries to fill the gap of the previous studies. Reference [4] shows that there is a significant relationship between E-S-Qual and E-Loyalty in Turkey. However, [13] study resulted opposingly.

$\mathrm{H} 1$ : There is a positive and significant relationship between E-Service Quality and Electronic Loyalty

Another research gap is that E-Recovery Service Quality does not influence E-Loyalty [14] whereas reference [4] found the opposite, that they have significant relationship. Thus, the hypothesis is

$\mathrm{H} 2$. There is a positive and significant relationship between ERecovery Service Quality and Electronic Loyalty

Since reference [15] shows there are partially supported relationship among E-S-Qual and E-RecS-Qual toward ELoyalty, [11] result is not the same. Thus, the hypothesis is
H3. There is positive and significant relationship among E-SQual and E-RecS-Qual toward E-Loyalty

\section{METHODOLOGY}

\section{A. Research Method}

The study was conducted from May-July 2017, using online and offline questionnaires. Five likert scales questionnaires is used for the study. Purposive sampling is used in this research. The respondents are Indonesian who have made at least a purchase in tokopedia (c2c) e-commerce in the last six months. The criteria would make the respondents able to recall their experiences when they purchased or browse the e-commerce and also to minimize errors due to memory. The address of online questionnaires was distributed via e-mail and WhatsApp messaging that leads to a structured questionnaires in google form and the offline questionnaires were distributed in Medan city, North Sumatera Province, Indonesia.. A total of 169 respondents are obtained from both online and offline questionnaires.

\section{B. Discussion and Conclusion}

The preliminary test of this study was conducted to 30 people to examine the validity and reliability of the questionnaire items before going on the actual sample size. Prior to validity and reliability instrument, an independent sample t-test was conducted to online and offline data, which showed no significant differences between them on the result, which also means both online and offline data can be used in the study.

The summary of the descriptive statistics from Indonesian C2C e-commerce is from Table 1 as follows: Most of respondents are between 17-23 years old, majority is male online shoppers who graduated from bachelor or professional bachelor degree with montly income between IDR 4.001 $6.000 \mathrm{k}$, and work for others. The purchase behavior profile is as follows, most of them purchased in the recent month with the frequency of once in a few months, who always consider online shopping as alternative. They mostly obtained information of e-commerce from electronic media and in the last six months, they have visited the e-commerce ten to ten times to compare prices among e-commerce sites, with the average time of six to ten minutes and more per one time surfing e-commerce sites. 
TABLE I. Descriptive Statistics

\begin{tabular}{|c|c|c|c|}
\hline Varable & & $\mathrm{n}$ & $\%$ \\
\hline \multirow[t]{6}{*}{ Ige } & Baneed 17.23 yeas & 57 & $34 \%$ \\
\hline & Batmen $24-30$ yeers & 44 & $26 \%$ \\
\hline & Betuen $31-37$ yeers & 35 & $21 \%$ \\
\hline & Betreen $38-44$ yeers & 20 & $12 \%$ \\
\hline & batmeen $45-51$ vezs & 6 & $4 \%$ \\
\hline & Above II yezs & 7 & $4 \%$ \\
\hline \multirow[t]{2}{*}{ Geader } & Náe & 92 & $54 \%$ \\
\hline & Fende & 77 & $46 \%$ \\
\hline \multirow[t]{3}{*}{ Bdxara } & Seric High & 30 & $19 \%$ \\
\hline & Thdergadzete & 101 & $60 \%$ \\
\hline & Posigadide & 38 & $22 \%$ \\
\hline \multirow[t]{6}{*}{ hoomemethy } & Bebrom DR 2,00\% & 43 & $25 \%$ \\
\hline & Batuen DR.2, $00 \%$ - 4,00\% & 3 & $2 \%$ \\
\hline & Bämen DR 4,001k - 6,000 & 48 & $28 \%$ \\
\hline & Batmeen DR 6,01k - 10,0006 & 29 & $17 \%$ \\
\hline & 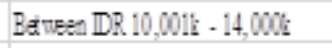 & 9 & $5 \%$ \\
\hline & Sbove DR . 14,00\% & 37 & $22 \%$ \\
\hline \multirow[t]{6}{*}{ Ooupation } & Stodent & 47 & $28 \%$ \\
\hline & Caiservat: & 6 & $4 \%$ \\
\hline & Employes & 54 & $32 \%$ \\
\hline & Evensoa: & 44 & $26 \%$ \\
\hline & Professived & 14 & $8 \%$ \\
\hline & Howerfe & 4 & $2 \%$ \\
\hline \multirow[t]{3}{*}{ Last oqine pacise } & Less than ameth as & 80 & $47 \%$ \\
\hline & ore to tree arths & 40 & $24 \%$ \\
\hline & ID e than the meths as & 49 & $29 \%$ \\
\hline \multirow[t]{4}{*}{ Freponcyofonie padase } & oce or me methy & 33 & $20 \%$ \\
\hline & oco in every fan moths & 106 & $63 \%$ \\
\hline & aenver & 16 & $9 \%$ \\
\hline & zely & 14 & $8 \%$ \\
\hline \multirow[t]{2}{*}{ Coxider cofre paciase a altenalse } & Yes & 149 & $88 \%$ \\
\hline & No & 20 & $12 \%$ \\
\hline \multirow[t]{2}{*}{ Orgin Souse of evominero iffemetion } & Frends Fanyecomendis & 49 & $29 \%$ \\
\hline & Betrocic mede (riemet, $\mathrm{N}$, etc) & 116 & $69 \%$ \\
\hline \multirow{4}{*}{$\begin{array}{c}\text { Fewency of ex mece wit in the lat } \\
\text { sin meths }\end{array}$} & Pritmedia & 4 & $2 \%$ \\
\hline & Onos & 28 & $17 \%$ \\
\hline & Iro to tentines & 81 & $48 \%$ \\
\hline & Nore the tentines & 60 & $36 \%$ \\
\hline \multirow[t]{6}{*}{ Prpose ofsrigg exmede } & fisl prinay yeds & 9 & $5 \%$ \\
\hline & fisl sexoraryreeds & 31 & $18 \%$ \\
\hline & fisl tesiayaxds & 32 & $19 \%$ \\
\hline & ompare pios & 64 & $38 \%$ \\
\hline & rindon shopeng & 31 & $18 \%$ \\
\hline & others & 2 & $1 \%$ \\
\hline \multirow[t]{6}{*}{ dvease ine persifig exomedo } & IDe or bss tha tro mistes & 4 & $2 \%$ \\
\hline & freeto fre nista and mee & 28 & $17 \%$ \\
\hline & six to ter mintes ad mee & 51 & $30 \%$ \\
\hline & elsed to thetymizes ax as & 35 & $21 \%$ \\
\hline & tuenlycoe to thity rivies and mee & 27 & $16 \%$ \\
\hline & 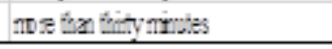 & 24 & $14 \%$ \\
\hline
\end{tabular}

\section{Validity and Reliability Tests}

For the Validity test, this study use $5 \%$ as the level of significance. If the correlation value (pearson correlation is bigger than $r$ table in which the 30 respondents is 0,361. And all the item correlation for variable E-S-Qual, E-RecS-Q and E-Loyalty is bigger than 0,361, so it means all items are valid.

On the reliability test, the value of Cronbach alpha in the reliability analysis must be bigger than 0,6 . Since all items in three variables in the study Cronbach alpha is bigger than 0,6 ; they are all reliable.

\section{Classical Assumption Test}

\section{1) Normality test}

Fig. 1. Normality Curve

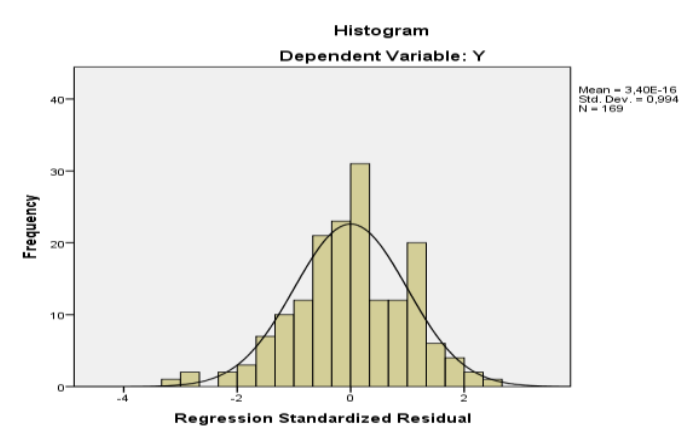

Source: Processed primary data (2017)

Fig. 2. P-P Plot of Regression Standardized Residual

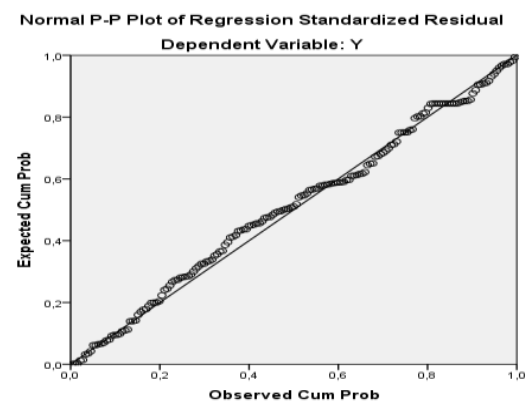

Source: Processed primary data (2017)

From the histogram, we could see that the data is distributed according to the curve, so it is normally distributed as the regression requirement. From the P-P Plot also the data is distributed well along the diagonal line, which means it passes normality test for regression. 


\section{E. Autocorrelation Test}

TABLE II. DURBin WATSON MOdel Summary

\begin{tabular}{|l|c|r|r|r|r|}
\hline Model & $\mathrm{R}$ & $\mathrm{R}$ Square & $\begin{array}{c}\text { Adjusted R } \\
\text { Square }\end{array}$ & $\begin{array}{c}\text { Std. Error of } \\
\text { the Estimate }\end{array}$ & $\begin{array}{c}\text { Durbin- } \\
\text { Watson }\end{array}$ \\
\hline 1 &, $636^{\mathrm{a}}$ &, 405 &, 398 & 6,83366 & 1,925 \\
\hline
\end{tabular}
a. Predictors: (Constant), E-RECOVERY SQ (X2), E-SERVICE
QUALITY (X1)
b. Dependent Variable: E-LOYALTY

From the Durbin watson table, $\mathrm{k}=2$ since there are two independent variables, with 169 respondents as sample, we obtained DU $=1,7724$. And based on table 2, the durbin watson value is 1,925 . It is called free of autocorrelation, if the Durbin Watson is between DU and 4- DU to fulfill regression requirement. Since $1,7724<1,925<3,7724$, it means it passed autocorrelation test.

\section{F. Multicollinearity Test}

TABLE III. TABLE OF COEFFICIENTS

\begin{tabular}{|c|c|c|c|c|c|c|c|c|}
\hline \multirow[b]{2}{*}{ Model } & & \multicolumn{2}{|c|}{ Unstandardiced Coefficentis } & \multirow{2}{*}{$\begin{array}{c}\begin{array}{c}\text { Standaricized } \\
\text { Coefficentis }\end{array} \\
\text { Beta }\end{array}$} & \multirow[b]{2}{*}{$t$} & \multirow[b]{2}{*}{ Sig. } & \multicolumn{2}{|c|}{ Collinearity Statisicics } \\
\hline & & B & Sito Error & & & & Tolerance & $V \mid F$ \\
\hline 1 & (Consiant) & 12,248 & 3,677 & & 3,331 & ,001 & & \\
\hline & E.SERVICE QUALLTY (XX) &, 340 & 0,055 &, 587 & 6,167 &, 000 &, 395 & 2,529 \\
\hline & E.RECOVERY SQ (X2) & 061 & ,094 & 061 & .643 & .521 & .395 & 2,529 \\
\hline
\end{tabular}

a. Dependent Variable: E-LOYALTY

Since the VIF value is not above 10 , it means there is no multicollinearity for each variables.

\section{G. Heteroscedasticity Test}

Fig. 3. Heteroscedasticity Test

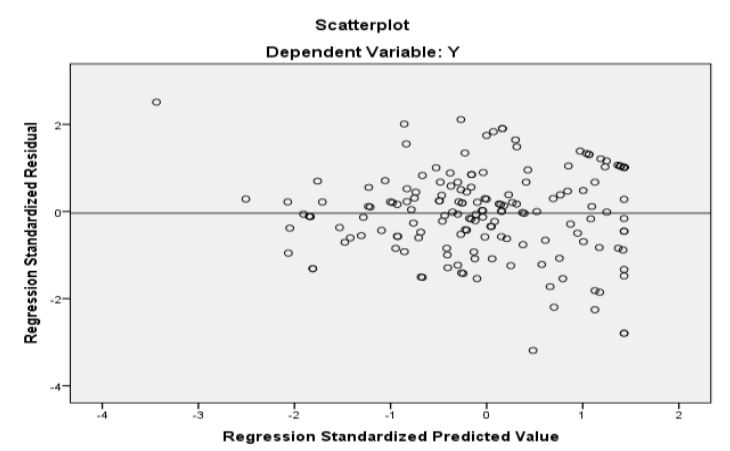

Source: Processed primary data (2017)

From the figure of scatterplot, we can see that the data is spread at zero line and not forming any pattern, so this data is free from heteroscedasticity.

\section{H. Regression Test}

This study uses regression analysis to test the hypotheses and to define relations directions. Multiple regression analysis using SPSS version 23 is applied with the goal of testing if ES-Qual and E-RecS-Qual have relationship with E-Loyalty. With the confidence level of $95 \%$, the result is shown on table 4.

TABLE IV. RESULT OF REGRESSION TEST

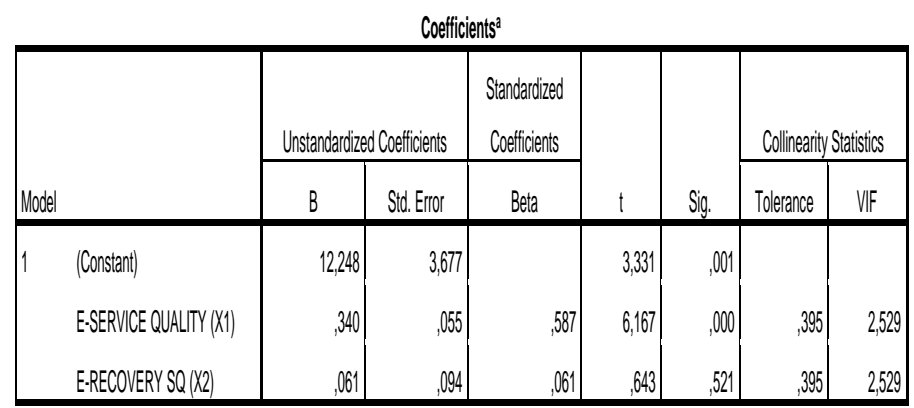

a. Dependent Varable: E-LOYALTY

$\mathrm{H} 1$. Since partial test is conducted, $\mathrm{t}$ table value is 1.97436 . If the significance is smaller than 0.05 or $t$ value $>t$ table, there is relationship between variables.

It is found that Sig.value between E-S-Qual and ELoyalty is $0,000<0,05$ and $\mathrm{t}$ count $6,167>\mathrm{t}$ tabel $=1.97436$ so that we can conclude that E-S-Qual has positive and highly significant influence towards E-Loyalty

H2. The result from table 4 has shown the Sig. Value between E-RecSQ and E-Loyalty is 0.521, which is bigger than 0.05 . Besides that, the $t$ value is 0.643 which is smaller than $\mathrm{t}$ table value 1.97436. Thus, it is concluded Hypothesis 2 is rejected, means that E-RecSQ partially has no influence towards E-Loyalty.

TABLE V. ANOVA TEST

\begin{tabular}{|c|c|c|c|c|c|c|}
\hline \multicolumn{7}{|c|}{ ANOVAa $^{a}$} \\
\hline Mo & & Sum of Squares & $d f$ & Mean Square & $\mathrm{F}$ & Sig. \\
\hline \multirow[t]{3}{*}{1} & Regression & 5269,641 & 2 & 2634,820 & 56,421 &, $000^{b}$ \\
\hline & Residual & 7752,028 & 166 & 46,699 & & \\
\hline & Total & 13021,669 & 168 & & & \\
\hline
\end{tabular}

a. Dependent Variable: E-LOYALTY

b. Predictors: (Constant), E-RECOVERY SQ (X2), E-SERVICE QUALITY (X1) 
H3. From Table 5, it is known that the significance level among E-S-Qual and E-RecS-Qual toward E-Loyalty is very high, which is 0.000 , smaller than 0.005 . The $F$ count is 56,421 , which is much bigger than $F$ table value 3.05 . Thus, it is concluded that Hypothesis 3 is accepted, there is a highly positive and significant relationship among E-S-Qual and ERecS-Qual toward E-Loyalty in simultenous test.

Therefore, the equation could be made as follows:

$\mathrm{Y}=\mathrm{a}+\mathrm{bX} 1+\mathrm{cX} 2+\mathrm{e}$

$\mathrm{Y}=12,248+0.340 \mathrm{X} 1+0.061 \mathrm{X} 2+\mathrm{e}$

Where $\mathrm{a}$ is the constanta and e is the error term, $\mathrm{X} 1$ is $\mathrm{E}-\mathrm{S}$ Qual, X2 is E-RecS-Q and Y is E-Loyalty. In order to find out the value of error term, we need to find the coefficient determination.

TABLE VI. MODEL SUMMARY

\begin{tabular}{|l|c|r|r|r|r|}
\hline Model & \multicolumn{1}{|c|}{ Model Summary } \\
\hline 1 &, $636^{\mathrm{a}}$ & R Square & $\begin{array}{c}\text { Adjusted R } \\
\text { Square }\end{array}$ & $\begin{array}{c}\text { Std. Error of the } \\
\text { Estimate }\end{array}$ & Durbin-Watson \\
\hline
\end{tabular}

a. Predictors: (Constant), E-RECOVERY SQ (X2), E-SERVICE QUALITY (X1)

b. Dependent Variable: E-LOYALTY

Based on Table 6, the output of $\mathrm{R}$ square is 0.405 , which means that the influence of E-S-Qual and E-RecS-Qual toward E-Loyalty is $40,5 \%$. The rest, is the error term, $59.5 \%$ is influenced by other independent variables which are not observed in this study.

\section{CONCLUSION AND RECOMMENDATION}

This study agrees with reference [4], that both E-S-Qual and E-RecS-Qual has positive and significant influence toward E-Loyalty. In order to increase profitability for Indonesia ecommerce, particularly in $\mathrm{C} 2 \mathrm{C}$, is by focusing on its electronic service quality and recovery service quality, in which its dimension of touch point, fulfillment, privacy, system availability, efficiency, responsiveness, contact and compensation play significant role to make online consumer loyal to e-commerce in Indonesia.

It is suggested to add moderating variables of trust, perception onto the future studies, if possible on a different ecommerce type.

\section{References}

[1] World Economic Forum, "World Economic Forum White Paper Digital Transformation of Industries", reports.weforum.org/.../wef-dticonsumerindustrieswhitepaper-final-january-2016.pdf, 2016. (Accessed on 15 September 2017)

[2] Nielsen, "Connected commerce report" http://www.nielsen.com/us/en/insights/reports/2017/the-nielsen-totalaudience-report-q1-2017.html. 2017 (Accessed on 15 September 2017)

[3] Yang, H. E. and Tsai F.S. "General E-S-Qual Scales Applied to Website Satisfaction and Loyalty Model." Communications of the IIMA, 2007, 7 (2):115-125.

[4] Zehir, Cemal dan Elif Narcikara. "E-Service Quality and E-Recovery Service Quality: Effects on Value Perceptions and Loyalty Intentions." Procedia - Social and Behavioral Sciences 229, 2016. pp. 427-443. Doi: 10.1016/j.sbspro.2016.07.153

[5] Parasuraman, A. Dan Valerie A. Zeithaml dan Arvind Malhotra. "E-SQUAL, A Multiple-Item Scale for Assessing Electronic Service Quality." Journal of Service Research. Vol. 7 No.X:1-21. 2005. Doi: $10.1177 / 1094670504271156$.

[6] Harris, L. C., and Goode, M. M. H. "The four levels of loyalty and the pivotal role of trust: A study of online service dynamics," Journal of Retailing (80:2) 2004, pp 139-158.

[7] Boston Consulting Group, "2010 Global Report on Consumer Senitment" https://www.bcg.com/documents/file51606.pdf. (Accessed on 15 September 2017)

[8] Nielsen, "Connected commerce report" http://www.nielsen.com/us/en/insights/reports/2017/the-nielsen-totalaudience-report-q1-2017.html. 2017 (Accessed on 15 September 2017)

[9] Cyr, D., Hassanein, K., Head, M., and Ivanov, A. "The role of social presence in establishing loyalty in e-service environments," Interacting with Computers, 2007, Vol.19:43-56.

[10] Hsin, H. C. \& W. W. Hsin , "The moderating effect of customer perceived value on online shopping behavior." Online Information Review, Vol. 35(3), 201, 333-359.

[11] Dharmesti, M.D.D. and Nugroho, S.S. , "The antecedents of online customer satisfaction and customer loyalty", Paper presented at International Trade \& Academic Research Conference, London,UK. . 2012, pp.37-45.

[12] Reichheld, F.F. and Schefter, P., "E-Loyalty", Harvard Business Review, Vol.78, No. 4, 2000, pp. 105-113.

[13] Chang, HsinHsin and Wang, Hsin-Wei, "Themoderating effect of customer perceived value on online shopping behavior." Online Information Review Vol. 35 No. 3, 2011, pp. 333-359.

[14] Wu, L. "Satisfaction, inertia, and customer loyalty in the varying levels of the zone of tolerance and alternative attractiveness." Journal of Services Marketing, 2011, 25(5): 310-32.

[15] Yaya, Luc Honore Petnji. "Customers' Loyalty and Its Antecedents and Perception of ISO 9001 in Online Banking." Dissertation. Universitat de Girona, Spain.2012. 